\title{
Histopathological Study of Guided Lung Biopsies
}

\author{
B. Garima, I.V. Renuka*, P. Ramya, Durga Prasad, Pravallika Uppala and Prathyusha \\ Dept of Pathology, NRI Institute of Medical Sciences, Chinakakani, Guntur, India
}

\begin{abstract}
Background: Guided lung biopsies and Fine needle aspiration cytologies (FNAC) have been used for diagnosis of peripheral lung lesions and both have advantages and disadvantages. In our institution, core needle biopsies of lung are done from Computed tomography (CT) and thoracoscopic guided procedures.

Methods: The histopathological records of our General Hospital were retrospectively reviewed forcore needle biopsies of lung lesions between July 2018 to June 2019 (1 year). There were 89 cases during this period.

Results: There were a total of 89 cases (66 males and 23 females) during the study period of one year . The specimens received were linear bits and average size was $0.5 \mathrm{~cm}$ in length. Non-neoplastic lesions were $24(26.9 \%)$ and neoplasms contributed to 65 cases $(73.03 \%)$. Maximum number of cases (47 cases) were reported in the age group of 41-60 years (47 cases) with male preponderance. In all the.age groups, malignant lesions were more common in which Adenocarcinoma was predominant.
\end{abstract}

Conclusion: To conclude, in our study malignancies predominated over non neoplastic lesions. The most common histological cell type encountered in this study was an Adenocarcinoma.

Keywords: Computed Tomography, Guided, Lung Biopsies, Adenocarcinoma.

\section{Introduction}

Small lung biopsies are the most common and the first lung sample obtained when a radiologic abnormality is detected and tissue diagnosis is required. ${ }^{[1]}$ Both CT guided FNA and core needle biopsies have been documented to be effective for diagnosis of peripheral lung lesions including non neoplastic and neoplastic lesions. ${ }^{[2]}$

CT guided biopsy may have an advantage over CT guided FNA for obtaining more tissue to perform Immunohistochemistry and/or molecular study. Image guided biopsies are less susceptible to false-negative or false positive diagnosis when compared with FNACs. ${ }^{[2]}$

Lung cancer is the commonest cancer and the biggest cause of cancer mortality worldwide. Every year lung cancer causes more than 1.6 million deaths, more than breast, colon, and prostate cancers combined..$^{[3]}$ Lung is also one of the most common metastatic sites of many primary cancers. ${ }^{[2]}$ Tissue is often required to differentiate primary from metastasis, benign lesions from malignant lesions and further classify a primary lung cancer for treatment.

However, the vast majorities of patients present with either locally advanced or metastatic disease and do not proceed to surgical resection so the diagnosis of lung cancer is confirmed using small biopsies/cytology. ${ }^{[4]}$

Among malignancies, Non small cell lung carcinoma is the most common lung cancer, accounting for about $85 \%$ of all cases. ${ }^{[5]}$ Small cell lung carcinoma is strongly related to cigarette smoking and metastasizes rapidly to many sites within the body and are most often discovered after they have spread extensively. Other factors include occupational exposures, air pollution and old pulmonary scar. ${ }^{[6]}$

Among non neoplastic lesions, Tuberculosis is the most common. Non-specific nature of symptoms and high prevalence of tuberculosis in our country, often leads to misdiagnosis and delayed diagnosis of lung cancer. ${ }^{[7]}$

The aim was to study the incidence of lung lesions in small biopsies in our institution accordingly with age and sex. Also to classify and subclassify tumors according to WHO guidelines so as to render a specific diagnosis.

\section{Materials and Methods}

Institutional ethics committee approval was obtained. The histopathological records of our General Hospital were retrospectively reviewed for core needle biopsies of lung lesions between July 2018 to June 2019 (1 year). There were 89 cases during this period.

Inclusion criteria : All the guided biopsies of lung were included in this study irrespective of them being non neoplastic and neoplastic, benign and malignant nature including primary and metastases.

Exclusion Criteria: Pleural and mediastinal biopsies were excluded from this study. Lobectomies and pneumonectomies were also not included in this study. 
The specimens were fixed in $10 \%$ formalin, subjected to routine tissue processing then paraffin embedded sections were made, followed by H\&E staining and slides were prepared. Information including age, sex, size and final diagnosis were collected from the records. Clinical history and radiological findings were also obtained.

\section{Results}

There were a total of 89 cases (66 males and 23 females) during the study period of one year. The specimens received were linear bits and average size was $0.5 \mathrm{~cm}$ in length. Non-neoplastic lesions were 24 (26.9\%) and neoplasms contributed to 65 cases $(73.03 \%)$. Maximum number of cases were reported in the age group of 41-60 years ( 47 cases) followed by 36 cases in persons aged 61 80 years and least in age group of 0-20 years with 6 cases only. In all the age groups, malignant lesions were more common.

The radiological location of the lesions, peripherally and central/hilar location were analysed. The most common histological cell type in peripherally and hilar regions located lesions was adenocarcinoma followed by squamous cell carcinoma.
Twenty four non neoplastic lesions were encountered, the most common being Inflammatory $(37.5 \%)$ followed by Tuberculosis (25\%) (Figure 1A), Interstitial fibrosis $(12.5 \%)$, Pneumonitis (8\%) (Figure 1B) and others (17\%). (Table no.1)

All 65 neoplastic lesions in our study were malignant. Among them, the most common histological type was Adenocarcinoma which accounted for 46 cases (71\%), 2 cases (3\%) being Mucinous Carcinoma and 44 cases (67\%) Non-mucinous adenocarcinoma. In 3 of the adenocarcinoma cases histology showed lepidic patterns as shown in Figure 2A,while rest 41cases showed acinar patterns.(Figure 2B). Eleven cases (17\%) of Squamous cell carcinoma were also reported.(Figure $3 \mathrm{~A} \& \mathrm{~B})$. Other malignant lesions were 3 cases $(4.5 \%)$ of Small cell carcinoma (figure 3C \&D), 3 cases $(4.5 \%)$ of Metastases which include one Adenocarcinomatous deposit from Gastrointestinal tract, one Clear cell carcinoma deposit from kidney and another was Extraskeletal Ewing's Sarcoma. Also one case $(1.5 \%)$ of Undifferentiated carcinoma and a case of Adenoid cystic carcinoma (1.5\%) were reported as shown in Table 2.

Table 1: Non neoplastic lesions of guided lung biopsies.

\begin{tabular}{|l|l|}
\hline Diagnosis & Number Of Cases \\
\hline Granulomatous Inflammation & $6(25 \%)$ \\
\hline Inflammatory & $9(37.5 \%)$ \\
\hline Interstitial Fibrosis & $3(12.5 \%)$ \\
\hline Pneumonitis & $2(8 \%)$ \\
\hline Others & $4(17 \%)$ \\
\hline Total & $\mathbf{2 4}$ \\
\hline
\end{tabular}

Table 2: Malignancies of guided lung biopsies.

\begin{tabular}{|l|l|}
\hline Neoplasms & Number \& Percentages \\
\hline $\begin{array}{l}\text { Adenocarcinoma } \quad \text { Mucinous } \\
\text { - Non Mucinous }\end{array}$ & $46(71 \%)$ \\
$2(3 \%)$ & $44(67 \%)$ \\
\hline Squamous Cell Carcinoma & $11(17 \%)$ \\
\hline Small Cell Carcinoma & $3(4.5 \%)$ \\
\hline Undifferentiated Carcinoma & $1(1.5 \%)$ \\
\hline Secondaries / Metastases & $3(4.5 \%)$ \\
\hline Adenoid Cystic Carcinoma & $1(1.5 \%)$ \\
\hline Total & 65 \\
\hline
\end{tabular}


Table 3: Comparison of malignancies with various studies.

\begin{tabular}{|c|c|c|c|c|c|c|c|c|c|}
\hline $\begin{array}{l}\text { Histologic } \\
\text { Types }\end{array}$ & $\begin{array}{l}\text { Present } \\
\text { study }\end{array}$ & $\begin{array}{l}\text { Agarwal } \\
\text { A et al }{ }^{[8]}\end{array}$ & $\begin{array}{l}\text { Malik PS } \\
\text { et al }{ }^{[5]}\end{array}$ & $\begin{array}{l}\text { Krishna- } \\
\text { murthy A et al[3] }\end{array}$ & $\begin{array}{l}\text { Sundaram } \\
\text { V et } \mathbf{a}^{[18]}\end{array}$ & $\begin{array}{l}\text { Li liang } \\
\text { et a }\left.\right|^{[2]}\end{array}$ & $\begin{array}{l}\text { Sarfraz S } \\
\text { et al }{ }^{[17]}\end{array}$ & $\begin{array}{l}\text { Mandal SK } \\
\text { et al }{ }^{[9]}\end{array}$ & $\begin{array}{l}\text { Kulshrestha } \\
\text { R et al }{ }^{[10]}\end{array}$ \\
\hline Adenocarcinoma & $71 \%$ & $29.3 \%$ & $37.3 \%$ & $42.6 \%$ & $43.33 \%$ & $30.3 \%$ & $3.75 \%$ & $30.8 \% \%$ & $12.8 \%$ \\
\hline $\begin{array}{l}\text { Squamous Cell } \\
\text { Carcinoma }\end{array}$ & $17 \%$ & $21.88 \%$ & $32.1 \%$ & $15.8 \%$ & $31.67 \%$ & $18.9 \%$ & $50 \%$ & $49.1 \%$ & $60.5 \%$ \\
\hline $\begin{array}{l}\text { Small Cell } \\
\text { Carcinoma }\end{array}$ & $4.5 \%$ & $12.8 \%$ & $28 \%$ & $13.1 \%$ & $10 \%$ & $8.33 \%$ & $15 \%$ & $14.8 \%$ & $12.8 \%$ \\
\hline $\begin{array}{l}\text { Undifferentiated } \\
\text { Carcinoma }\end{array}$ & $1.5 \%$ & $24 \%$ & $0.5 \%$ & $6.9 \%$ & $11.67 \%$ & - & - & $1.5 \%$ & $10.1 \%$ \\
\hline Metastases & - & $6.4 \%$ & - & - & - & - & $6.25 \%$ & - & - \\
\hline
\end{tabular}

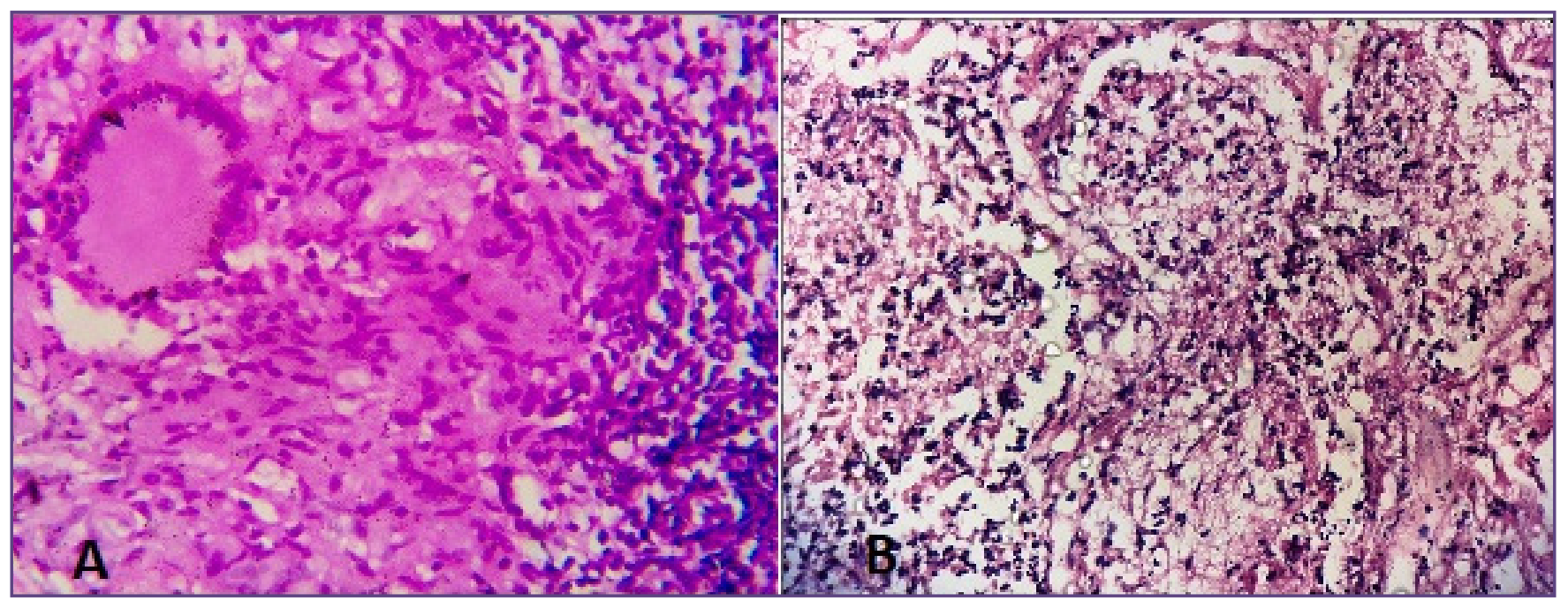

Fig. 1: A - Tuberculosis showing epithelioid cell collections and langhan's giant cell, (H\&E 400X); B - Pneumonia showing neutrophilic collections both in interstitium and alveoli, (H\&E 100X).

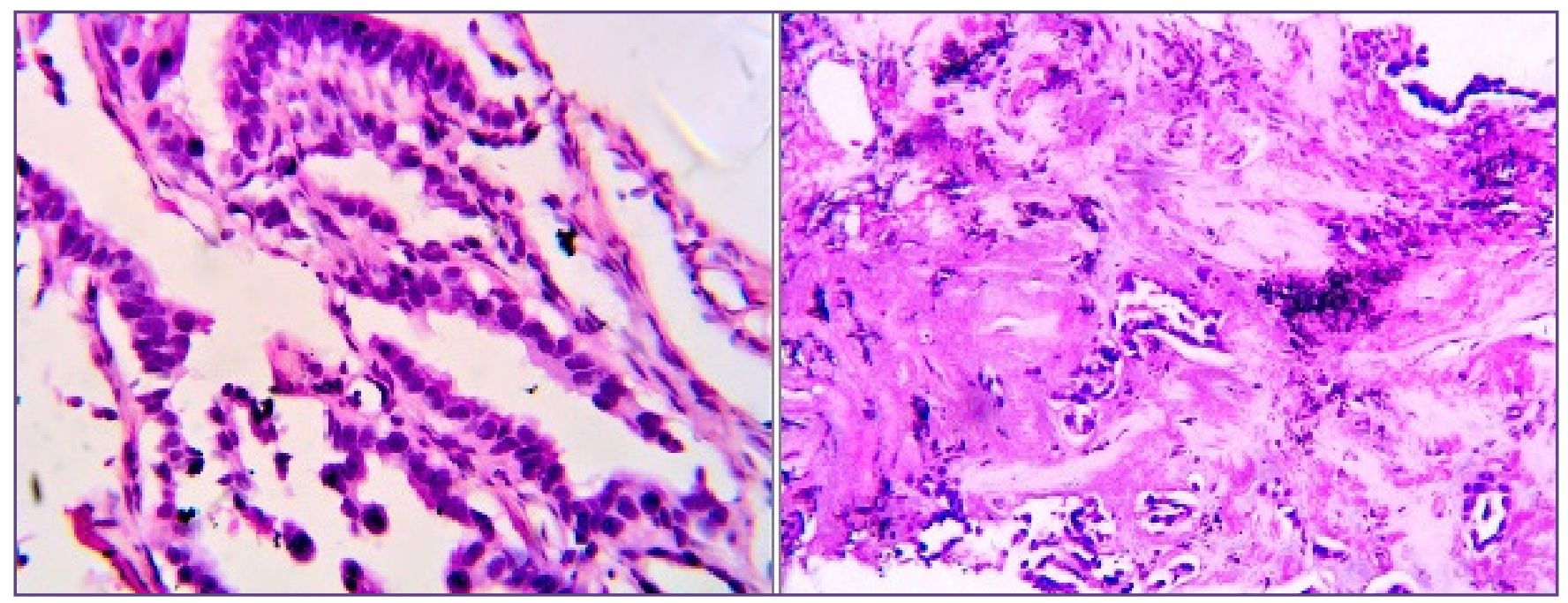

Fig. 2: A- Adenocarcinoma with lepidic growth pattern , (H\&E 400X); B - Acinar adenocarcinoma (Non-mucinous) showing acinar and glandular growth patterns,(H\&E 100X). 


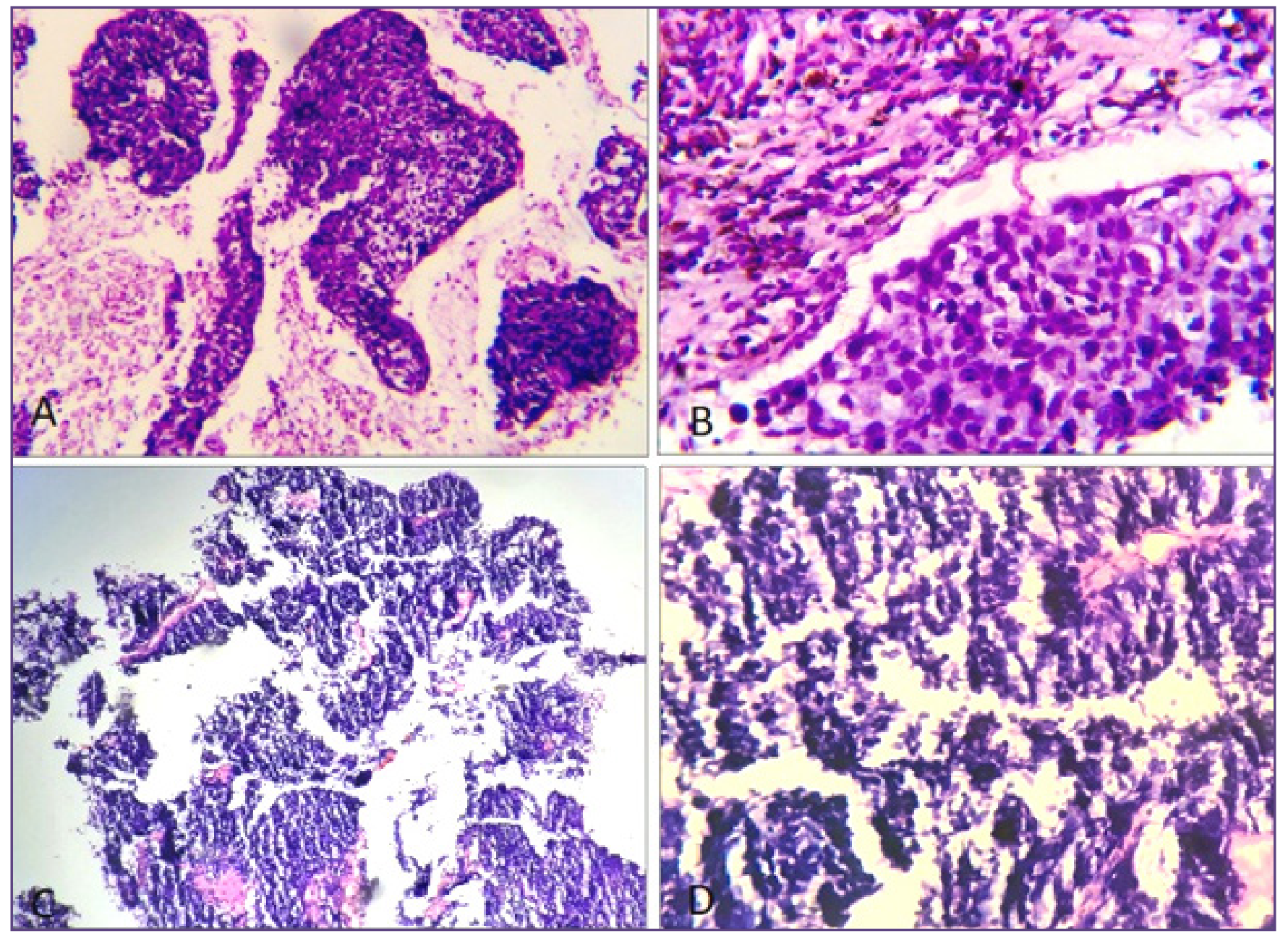

Fig. 3: A-Moderately differentiated Squamous cell carcinoma,(H\&E 100X); B - Higher power showing cells with pleomorphism, mitoses and nuclear hyperchromatism, (H\&E 400X); C\& D - Small cell carcinoma , (H\&E 100X \& 400X).

\section{Discussion}

There were a total of 89 cases during the study period of 1 year, majority of them were seen in $4^{\text {th }}$ to $6^{\text {th }}$ decade, whereas in studies done by Agarwal A et a ${ }^{[8]}$ and Malik PS et al, ${ }^{[5]} 5^{\text {th }}$ to $6^{\text {th }}$ decade was the common age group affected.

The male to female ratio in the present study was $5.3: 1$ and in studies done by Agarwal et al, ${ }^{[8]}$ Malik PS et al ${ }^{[5]}$ and Mandal SK et al ${ }^{[9]}$ et al the ratios were 4.7:1, 4.6:1 and 1:1 respectively.

In our study malignancies were more common than non neoplastic lesions accounting to 65 cases out of 89 which was in contrast to a study done by Kulshrestha R et $\mathrm{al}^{[10]}$ where non neoplastic lesions were more common constituting to 506 non neoplastic lesions out of 916 cases.

The lung malignancies were common in age group 41-60 years and mean age was 57.26 years which was comparable to studies done by Koul PA et al, ${ }^{[11]}$ Noronha V et al, ${ }^{[7]}$ Dey A et $\mathrm{al}^{[12]}$ where $57.6,56,57.9$ respectively were the mean age.

The malignancies showed male preponderance and male to female ratio was 2.8:1, similar to studies done by Pandhi $\mathrm{N}$ et al, ${ }^{[13]}$ Gupta et al, ${ }^{[14]}$ Kumar et al, ${ }^{[15]}$ Dhandapani et al. ${ }^{[16]}$ This showed that in India, females have still lower prevelance of smoking. ${ }^{[17]}$

The most common malignancy encountered in our study was Non small cell carcinoma among which Adenocarcinoma (46 cases, 71\%) was most common which was similar to studies done by Agarwal A et al, ${ }^{[8]}$ Malik PS et al, ${ }^{[5]}$ Krishnamurthy et al, ${ }^{[3]}$ Sundaram et al, ${ }^{[18]}$ Li Liang et al, ${ }^{[2]}$ whereas in the studies done by Sarfraz $\mathrm{S}$ et al, ${ }^{[17]}$ Mandal SK et al, ${ }^{[9]}$ and Kulshrestha $\mathrm{R}$ et al, ${ }^{[10]}$ and Gupta $\mathrm{R}$ et al, ${ }^{[14]}$. Squamous cell carcinoma was the most common malignancy as shown in Table no. 2 . 
Radiologically, the maximum number of malignancies in our study were located in peripheral regions (78 cases) where Adenocarcinoma was the commonest followed by Squamous cell carcinoma which was similar to the study done by Agarwal A et al, ${ }^{[8]}$ and Rawat J et al. ${ }^{[19]}$ Most of the lesions in our study and the study by Agarwal A et $\mathrm{al}^{\left[{ }^{[8]}\right.}$ involved the right lobe of lung rather than the left . In present study most of the adenocarcinomas presented as mass lesion (60\%) followed by pleural effusion (11\%) which was similar to studies done by Rawat $\mathrm{J}$ et al ${ }^{[19]}$ and Sarfraz S et al. ${ }^{[17]}$

Most studies from India had reported squamous cell carcinoma as the most dominant subtype, but many recent studies from India too show changing trends and have reported Adenocarcinoma as the predominant subtype. ${ }^{[20]}$

The second common histological type was Squamous cell carcinoma (11 cases) which was similar to studies done by Malik PS et $\mathrm{al}^{[5]}$ (56 cases), Agarwal A et al ${ }^{[8]}$ (86 cases) and $\mathrm{Li}$ Liang et $\mathrm{al}^{[2]}(25$ cases)(Table no.30. In this study 9 out of 11 cases $(81.8 \%)$ presented as hilar mass similar to studies done by Gupta $\mathrm{R}$ et $\mathrm{al}^{[14]}$ and Sarfraz $\mathrm{S}$ et al. ${ }^{[17]}$ We had 3 cases of small cell carcinoma all of them were centrally located similar to studies done by Gupta R et $\mathrm{al}^{[14]}$ and Rawat $\mathrm{J}$ et al. ${ }^{[19]}$

Table no. 3 shows occurrence of malignancies encountered in our study in comparison with other studies

Among the non neoplastic group, majority in our study were diagnosed as inflammatory lesions (9 cases, $37.5 \%$ ) which mostly included chronic inflammatory cell collections like lymphocytes. This was followed by 6 cases $(25 \%)$ of Granulomatous inflammation in which 5 of them showed presence of caseating granulomas, langhan type of giant cells, lymphocytic collections and caseating necrosis suggesting Tuberculosis. In one case there was non caseating granuloma. (Fig 1A).

This was in contrast to the study done by Kulshrestha $\mathrm{R}$ et $\mathrm{al}^{[10]}$ where most of the cases were granulomatous lesions $(30.2 \%)$ followed by inflammatory lesions and fibrosis. The study of Li Liang et $\mathrm{al}^{[2]}$ also had more cases of granulomatous lesions.(51.8\%) There were also 3 cases of Interstitial fibrosis(12.5\%), one case of non resolving Pneumonia(4\%)(Fig 1B) and a single case of Interstitial pneumonitis (4\%).

\section{Conclusion}

To conclude, in our study malignancies predominated over non neoplastic lesions in incidence among young as well as in old patients. The most common histological cell type encountered in this study was an Adenocarcinoma, which reflects the rise in its prevalence. In the present study, Non specific inflammation was the most common non neoplastic condition followed by Granulomatous inflammation with Tuberculosis being the most common.

\section{Reference}

1. Mukhopadhyay S, Mehta AC. Utility of Core needle biopsies and transbronchial biopsies for diagnosing Nonneoplastic lung diseases. Arch Pathol Lab Med 2018;142:1054-1068.

2. Li Liang, Jing L, Buryanek J, Zhang S. CT-guided core needle biopsy of peripheral lung lesions with onsite adequate evaluation: Review of 215 cases. J Cytol Histol 2014;4:1-5.

3. Krishnamurthy A, Vijaylakshmi R, Gadigi V, Rangananthan R, Sagar T G. The relevance of "Nonsmoking- associated lung cancer" in India. A single-center experience. Indian J Cancer 2012;49:82-8.

4. Davidson MR, Gazdar AF, Clarke BE. The pivotal role of pathology in the management of lung cancer. J Thorac Dis 2013;5:463-478.

5. Malik PS, Sharma MC, Mohanti BK, Shukla NK, Deo SV, Mohan A, et al. Clinico- pathological profile of lung cancer at AIIMS: a changing paradigm in India. Asian Pac J Cancer Prev 2013;14:489-94.

6. Inamura K. Lung cancer : Understanding its molecular pathology and the 2015 WHO classification. Front. Oncol 2017;7:1-6.

7. Noronha V, Dikshit R, Raut N, Joshi A, Pramesh CS, George $\mathrm{K}$, et al. Epidemiology of lung cancer in India. Focus on the differences between non-smokers and smokers: A singlecentre experience. Indian J Cancer 2012;49:74-81.

8. Agarwal A, Tandon R, Singh L, Kumar P, Pant H. Clinical profile of lung cancer in a tertiary care teaching hospital in North India with special reference to acceptance and outcome of treatment. J Pulmon 2018;2:4-8.

9. Mandal SK, Singh TT, Sharma TD, Amrithalingam V. Clinico-pathology of lung cancer in a regional cancer centre in Northeastern India. Asian Pac J Cancer Prev 2013; 14:7277-81.

10. Kulshrestha R, Menon BK, Vijayan VK. Role of a pattern based approach in interpretation of transbronchoscopic lung biopsy and its clinical implications. The Indian Journal of Chest diseases and allied sciences 2012;54:9-17.

11. Koul PA, Kaul SK, Sheikh MM, Tasleem RA, Shah A. Lung cancer in the Kashmir valley. Lung India 2010;27:131-137.

12. Dey A, Biswas D, Saha SK, Kundu S, Sengupta A. Comparison study of clinicoradiological profile of primary lung cancer cases: An Eastern India experience. Indian J Cancer 2012;49:89-95.

13. Pandhi N, Malhotra B, Kajal N, Prabhudesai RR, Nagaraja CL, Mahajan N. Clinicopathological profile of patients with lung cancer visiting Chest and TB Hospital Amritsar. Sch.J.App.Med.Sci 2015;3:802-809. 
14. Gupta R, Chowdary I, Singh P. Clinical, radiological and histological profile of primary lung carcinomas. JK Science 2015;17:146-151.

15. Kumar M, Sharma DK, Garg M, Jain P. Clinicopathological profile of lung cancer - changing trends in India. Int.J Res Med 2016;5:57-62.

16. Dhandapani S, Srinivasan A, Rajgopalan R, Chellamuthu S, Rajkumar A, Palaniswamy P. Clinicopathological profile of lung cancer patients in teaching hospital in South India. J Cardiothorac Med 2016;4:442-443.

17. Sarfraz S, Gupta R, Bhardwaj S. Histopathological Patterns of endobronchial lung biopsy specimen in lung cancer along with clinico-radiological correlation. International Journal of Contemporary Medical Research 2018;5:1-5.

18. Sundaram V, Sanyal N. Clinicopathological profile of bronchogenic carcinoma in a tertiary care hospital in eastern part of India. Clin Cancer Investig J 2014;3:220-224.

19. Rawat J, Sindhwani G, Dushyant G, Clinicopathological profile of lung cancer in Uttarakhand. Lung India 2009;26:74-76.

20. Prasad R, James P, Kesarwani V, Gupta R, Pant MC, Chaturvedi A, Shrivastava AN. Clinco-pathological study of bronchogenic carcinoma. Respirology 2004;9:557-60.

*Corresponding author:

Dr. I.V. Renuka, Professor \& Head of Department, Pathology, NRI Institute of Medical Sciences, Chinakakani, Guntur, India

Phone: +91 9848134166

Email: repriya56@gmail.com

Financial or other Competing Interests: None. 